\title{
Effect of an intra-uterine fluid accumulation before and after the first postpartum ovulation on pregnancy rates in the mare
}

\author{
A. Schilela', E. Malschitzky', Ana Luiza Gelpi Mattos², Petra Garbade', R.M. Gregory' and R.C. Mattos' \\ 1 Reprolab, Departamento de Medicina Animal, Faculdade de Veterinária, UFRGS, Porto Alegre, RS, Brazil \\ 2 Departamento de Medicina Veterinária, ULBRA, Canoas, RS, Brazil
}

\begin{abstract}
Summary
The present study aimed to verify (a) if the presence of fluid in uterine lumen during foal-heat was related to the post-breeding presence of fluid; (b) if treating mares with fluid accumulation during foal-heat (b1) decreased the incidence of post-breeding fluid accumulation and (b2) improved pregnancy rates during foal-heat; and (c) if post-breeding treatments improved pregnancy rates in mares with post-breeding uterine fluid accumulation. One hundred and sixty two Thoroughbred mares with ages from 4 to 23 years were studied. Fifty-seven mares presented fluid during heat and $35.1 \%$ of them retained fluid after ovulation. This result was superior $(p<0.05)$ to that found in mares that did not retain fluid during heat $(n=73 ; 15.1 \%)$. Treatments with oxytocics in mares retaining fluid during heat neither decreased the incidence of postbreeding fluid, nor improved pregnancy rates, in comparison to not treated mares. Uterine flushes performed $36-48 \mathrm{~h}$ after breeding in mares with post-breeding fluid accumulation $(n=31)$ did not provide satisfactory pregnancy rates $(48.4 \%)$, results being significantly inferior $(p<0.05)$ than those observed in mares without post-breeding uterine fluid accumulation $(n=99 ; 74.7 \%)$. It was concluded that mares that show uterine fluid accumulation during foal-heat also present a larger incidence of post-breeding fluid accumulation. It was also observed that treatments with oxytocics in mares presenting fluid during foal-heat neither decrease the incidence of post-breeding fluid accumulation, nor improve pregnancy rates. Uterine flushes performed 36-48 h after breeding in mares with uterine fluid after foal-heat ovulation do not improve pregnancy rates.
\end{abstract}

Keywords: $\quad$ intrauterine fluid, foal-heat, pregnancy rates

\begin{abstract}
Einfluss einer intrauterinen Flüssigkeitsakkumulation vor und nach der ersten postpartalen Ovulation auf die Trächtigkeitsrate bei Stuten

Die vorliegende Arbeit diente der Klärung folgender Fragen: a.) Besteht ein Zusammenhang zwischen einer intrauterinen Flüssigkeitsakkumulation in der Fohlenrosse und einer solchen nach der Belegung? b.) Führt eine Behandlung solcher flüssigkeitsbelasteten Stuten in der Fohlenrosse b1.) zu einer Reduktion nach der folgenden Belegung und b2.) zu einer positiven Beeinflussung der Trächtigkeitsrate bei Belegung in der Fohlenrosse? c.) Beeinflusst eine Behandlung flüssigkeitsbelasteter Stuten nach der Belegung zu einer Verbesserung der Trächtigkeitsrate? Untersucht wurden 162 Vollblutzuchtstuten im Alter zwischen 4 und 23 Jahren. 57 Patientinnen zeigten in der Fohlenrosse bereits eine präovulatorische intrauterine Flüssigkeitsakkumulation, die bei 35,1\% nach der Ovulation persistierte. Demgegenüber entwickelten von den 73 präovulatorisch nicht betroffenen Stuten $11(15,1 \%)$ eine postovulatorische intrauterine Flüssigkeitsakkumulation, d.h. bereits präovulatorisch vorbelastete Stuten sind signifikant häufiger $(p<0,05)$ betroffen. Eine Behandlung mit Oxyłocinpräparaten der flüssigkeitsbelasteten Stuten beeinflusste weder das Auftreten einer solchen nach Belegung noch die Trächtigkeitsrate, verglichen mit den nicht behandelten Kontrollen. Uterusspülungen 36-48h nach Bedeckung bei flüssigkeitsbelasteten Stuten ( $n=31)$ zeigten keine zufriedenstellenden Trächtigkeitsraten (48,4\%), die signifikant $(p<0,05)$ unter denjenigen nicht belasteter Stuten lagen $(n=99,74,7 \%)$. Es kann zusammenfassend festgestellt werden, dass Stuten mit intrauteriner Flüssigkeitsakkumulation in der Fohlenrosse ebenfalls häufiger eine solche nach Belegung aufweisen. Darüber hinaus führt die Behandlung mit Oxytocinpräparaten in der Fohlenrosse weder zu einer Reduktion hinsichtlich der Inzidenz einer Flüssigkeitsbelastung nach Belegung noch zu einer erhöhten Befruchtungsrate. Uterusspülungen 36-48h nach Belegung flüssigkeitsbelasteter Stuten verbessern ebenfalls nicht die Befruchtungsraten.
\end{abstract}

Schlüsselwörter: intrauterine Flüssigkeit, Fohlenrosse, Trächtigkeitsrate

\section{Introduction}

A strategy to obtain an interval of less than 12 months between foalings is to breed mares during foal-heat. However, studies that evaluated the reproductive efficiency of foal-heat have produced conflicting results. Some reports indicated that pregnancy rates and embryonic death (ED) did not differ between foal-heat and subsequent estrus (Saltiel et al., 1987; Mattos et al., 1995), while other studies have demonstrated pregnancy rates 10-30\% lower in foal-heat (Merkt and Günzel, 1979; Ginther, 1992) and greater rates of embryonic death (Merkt and Günzel, 1979, Ball, 1993). Kurtz Filho et al. (1999) working with 578 Southern Brazilian Thoroughbred mares, observed lower pregnancy rates and a greater incidence of embryonic death in mares bred in foal-heat than in those bred to subsequent heats. Factors that are thought to contribute to this lower reproductive efficiency are uterine involution, accumulation of intra-uterine fluid and decreased efficiency of the mechanisms which protect the uterus from post-breeding contamination (Saltiel et al., 1987).

McKinnon et al. (1988) studying alterations in the uterus during foal-heat, found that $74.4 \%$ of evaluated mares accumulated 
liquid in the lumen of the uterus (intrauterine fluid, IUF) during this heat. They also demonstrated that the pregnancy rate of mares presenting an accumulation of IUF was significantly less (33\%) than in mares which did not accumulate IUF (84\%). The presence of IUF before breeding may be an indication of susceptibility to persistent post-breeding endometritis in barren mares (Pycock and Newcombe, 1996). In such mares, the uterine defense mechanisms seem to be insufficient in preventing breeding-induced endometritis, which is considered to be an important cause of infertility in mares (Hughes and Loy, 1975). The objectives were to verify 1) whether the presence of IUF during foal-heat is associated with the presence of post-breeding IUF, 2) whether treatment of mares which accumulate IUF during foal-heat could reduce the occurrence of post-breeding IUF and increase pregnancy rates, and 3) whether post-breeding treatments increase pregnancy rates in mares that accumulate post-breeding IUF when mated during foal-heat.

\section{Materials and methods}

The study was conducted in a Thoroughbred breeding center in Southern Brazil during the breeding seasons 1999 and 2000. Animals used included 162 Thoroughbred mares with ages between 4 and 23 years and 12 proven fertile Thoroughbred stallions.

\section{Reproductive management}

All births were assisted and, when necessary, the perineum of the mares was repaired 30 minutes after foaling. Only mares having uncomplicated parturition were used in the study. Mares were kept on pasture and fed a concentrate mix twice daily.

Beginning on day 5 postpartum, the uteri of all mares were examined repeatedly using rectal palpation and ultra-sound to evaluate follicular growth, degree of uterine edema and presence or absence of IUF. Examinations were repeated at intervals not greater than 48 hours until a preovulatory follicle (>40mm) was detected. From that moment on, examinations were performed every 24 hours, until the observation of reduction in the degree of uterine edema, which was considered as the ideal mating time. An additional examination was conducted 36 to 48 hours after breeding to confirm ovulation and to evaluate the uterus.

Pregnancy was diagnosed at 12 days after ovulation, using real-time mode $\mathrm{B}$ ultra-sound scanner fitted with a $5 \mathrm{MHz}$ linear transducer. When an embryonic vesicle was detected, the mare was examined weekly until day 45 of pregnancy. Twins were reduced manually before day 16 of pregnancy. Embryonic death was considered as having occurred when gestation was interrupted between D12 and D45.

\section{Experiment 1}

The objective of this experiment was to verify if the presence of IUF during foal-heat and after breeding influenced pregnancy rate. This study used 135 postpartum mares, which were examined repeatedly for IUF from the $5^{\text {th }}$ postpartum day until mating at intervals not greater than 48 hours. The observation of accumulated liquid in the uterine lumen by ultra-sound in any of the examinations was considered as presence of IUF.

\section{Experiment 2}

The objective of this experiment was to verify if treatments of mares accumulated IUF during foal-heat reduced the occurrence of post-breeding IUF and increased pregnancy rates.

In this experiment, 89 mares presenting IUF during foalheat were assigned randomly to the following groups: 1) untreated control, 2) treatment with methyl-ergonovine maleate (Methergin, Sandoz, $25 \mathrm{mg} /$ day IM) from day 5 to day 10 postpartum and 3) a single dose of methyl-ergonovine maleate (Methergin, Sandoz, 25 mg IM) at 6 to 12 hours after breeding.

\section{Experiment 3}

The objective of this experiment was to determine whether postbreeding uterine flushes with saline solution and treatment with oxytocin increased pregnancy rates in mares that accumulated IUF after breed during foal-heat.

In this experiment, 120 mares in foal-heat were examined from day 5 postpartum to detect the best moment to breed. At the first post-breeding examination conducted 36 to 48 hours after mating, the mares were divided into groups according to the detection of IUF. Group 1 (G1) contained mares without IUF at the first examination. Mares in Group 2 (G2) were detected with IUF at the first examination, and were immediately submitted to at least three successive uterine flushes (each with $2 \mathrm{~L}$ of saline) followed by oxytocin (20 IU, I.V.) administration.

\section{Statistical Analysis}

Pregnancy rates, embryo death rates and the frequency of IUF were compared using the Chi-square test. Differences were considered significant at the $5 \%$ level.

\section{Results}

The results of Experiment 1 are shown in Tables 1 and 2.

Tab. 1: Occurrence of intrauterine fluid (IUF) accumulation after foalheat ovulation in mares with and without IUF during foal-heat.

Häufigkeitsverteilung intrauteriner postovulatorischer Flüssigkeitsakkumulationen (IUF) in der Fohlenrosse bei Stuten mit oder ohne präovulatorische Flüssigkeitsakkumulation.

\begin{tabular}{|l|c|c|c|}
\hline & mares & \multicolumn{2}{|c|}{ Post-ovulation IUF } \\
Foal-heat IUF & $\mathbf{n}$ & $\mathbf{n}$ & IUF Positive (\%) \\
\hline Absence & 73 & 11 & $15.1^{\mathrm{a}}$ \\
\hline Presence & 57 & 20 & $35.1^{\mathrm{b}}$ \\
\hline
\end{tabular}

Different superscripts $(a, b)$ in the same column indicate significant differences between values $\left(p<0.01 ; c^{2}=7.06\right)$. 
Tab. 2: Effect of presence of intrauterine fluid (IUF) between day 5 postpartum and breeding on the pregnancy rate of mares bred during foal-heat.

Einfluss einer intrauterinen Flüssigkeitsbelastung (IUF) zwischen dem 5. Tag post partum und der Belegung in der Fohlenrosse auf die Trächtigkeitsrate.

\begin{tabular}{|c|c|c|c|c|c|c|}
\hline \multirow[t]{2}{*}{$\begin{array}{l}\text { Foal- } \\
\text { heat IUF }\end{array}$} & \multirow{2}{*}{$\begin{array}{c}\text { mares } \\
\text { n }\end{array}$} & \multicolumn{2}{|c|}{$\begin{array}{c}\text { Pregnant at } 14 \\
\text { days }\end{array}$} & \multicolumn{2}{|c|}{$\begin{array}{c}\text { Pregnant at } 42 \\
\text { days }\end{array}$} & \multirow{2}{*}{$\begin{array}{l}\text { ED } \\
\text { (\%) }\end{array}$} \\
\hline & & $n$ & (\%) & $n$ & (\%) & \\
\hline Absence & 78 & 54 & $69.2^{a}$ & 46 & $58.9^{a}$ & 14.8 \\
\hline Presence & 57 & 37 & $64.9^{a}$ & 28 & $49.0^{\circ}$ & 24.3 \\
\hline
\end{tabular}

Same superscripts (a) within each column indicate no significant difference $(p>0.05)$.

The presence of IUF after ovulation was significantly $(p<0.01)$ more frequent in mares which accumulated IUF during foal-heat (Table 1). However, the presence of IUF during foal-heat did not influence the pregnancy rate of these mares when compared to the pregnancy rate of mares without IUF (Table 2).

The results of Experiment 2 are shown in Tables 3 and 4.

Tab. 3: Effect of treatment with Methylergonovine maleate (Methergin ) on the occurrence of intrauterine fluid (IUF) accumulation after foalheat ovulation in mares that presented IUF between day 5 postpartum and breeding.

Einfluss einer Behandlung mit Methylergonovin-Maleat (Methergin ) auf prä- und postovulatorisch (Fohlenrosse) flüssigkeitsbelastete Stuten (IUF).

\begin{tabular}{|l|c|c|c|}
\hline & mares & \multicolumn{2}{|c|}{ Post-ovulation IUF } \\
Treatments & $\mathbf{n}$ & $\mathbf{n}$ & IUF Positive (\%) \\
\hline T1 ñ Control (not treated) & 57 & 20 & $35.1^{\mathrm{a}}$ \\
\hline T2 - Methergin D5 ñ D10 & 17 & 7 & $41.2^{\mathrm{a}}$ \\
\hline T3 ñ Methergin post-breeding & 10 & 5 & $50.0^{\mathrm{a}}$ \\
\hline
\end{tabular}

Same superscripts (a) within each column indicate no significant difference $(p>0.05)$.

Tab. 4: Effect of treatment with Methylergonovine maleate (Methergin ) on pregnancy rates in mares bred in foal-heat that presented IUF between day 5 postpartum and breeding.

Einfluss einer Behandlung mit Methylergonovin-Maleat (Methergin) auf die Trächtigkeitsrate bei Stuten (Belegung in der Fohlenrosse), die zwischen dem 5. Tag post partum und der Belegung eine intrauterine Flüssigkeitsakkumulation aufwiesen.

\begin{tabular}{|l|c|c|c|c|c|c|}
\hline & & \multicolumn{2}{|c|}{$\begin{array}{c}\text { Pregnant } \\
\text { at 14 days } \\
\text { Treatment }\end{array}$} & \multicolumn{2}{|c|}{$\begin{array}{c}\text { Pregnant at } \\
\text { 42 days } \\
\text { (\%) }\end{array}$} & ED \\
\hline (\%) & (\%) \\
\hline T1 ñ Control (not treated) & 57 & 37 & $64.9^{\circ}$ & 28 & $49.1^{\circ}$ & 24.3 \\
\hline T2 - Methergin D5 ñ D10 & 17 & 12 & $70.5^{\circ}$ & 8 & $47.1^{\circ}$ & 33.3 \\
\hline $\begin{array}{l}\text { T3 ñ Methergin post- } \\
\text { breeding }\end{array}$ & 10 & 5 & $50.0^{\circ}$ & 4 & $40.0^{\circ}$ & 20.0 \\
\hline
\end{tabular}

Same superscripts (a) within each column indicate no significant difference $(p>0.05)$.
When compared to the control group (T1), the different treatments given to the mares which accumulated IUF during foal-heat did not reduce $(p>0.05)$ the incidence of postbreeding IUF (Table 3), nor did the treatments significantly improve $(p>0,05)$ pregnancy rates (Table 4$)$.

The results of Experiment 3 are shown in Table 5

Tab. 5: Effect of presence of intrauterine fluid (IUF) 36-48 hours after breeding on pregnancy rates of Thoroughbred mares bred to foal-heat.

Einfluss einer intrauterinen Flüssigkeitsakkumulation (IUF) 36-48 nach der Belegung in der Fohlenrosse auf die Trächtigkeitsrate bei Vollblutzuchtstuten.

\begin{tabular}{|l|c|c|c|c|c|c|}
\hline Mares & & \multicolumn{2}{|c|}{$\begin{array}{c}\text { Pregnant } \\
\text { at 14 days } \\
\text { (\%) }\end{array}$} & \multicolumn{2}{|c|}{$\begin{array}{r}\text { Pregnant at } \\
\text { 42 days } \\
\text { (\%) }\end{array}$} & ED \\
\hline G1 ñ without IUF & 99 & 74 & $74,7^{a}$ & 60 & $60,6^{c}$ & 18,9 \\
\hline G2 - with IUF + treatment & 31 & 15 & $48,4^{\text {b }}$ & 13 & $41,9^{d}$ & 13,3 \\
\hline
\end{tabular}

Different superscripts $(a, b)$ in the same column indicate significant difference between values $\left(p<0.01 ; c^{2}=7.59\right)$.

Different superscripts $(c, d)$ in the same column indicate a significant difference between values $\left(p<0.01 ; c^{2}=7.06\right)$.

Mares that did not have IUF accumulation after breeding ( $G 1$ ) had greater $(p<0.01)$ pregnancy rates than mares which presented an accumulation of IUF after breeding and underwent treatment (Table 5, G2).

\section{Discussion}

With regard to the presence of IUF during foal-heat, it was observed that only $43.8 \%$ of the mares studied presented IUF, a proportion that is less than that reported by McKinnon et al. (1988) (74.4\%). The differences between the two studies may have been caused by differences of age, management, or methods used, i.e., McKinnon et al. (1988) started examining mares on day 3 postpartum, whereas in our study we started on day 5 postpartum. In contrast to the data of McKinnon et al. (1988), in this study pregnancy rates of mares that accumulated IUF during foal-heat did not differ from those observed in mares which did not present IUF between the 5th postpartum day and the first ovulation. These results are similar to those observed by Reilas et al. (1997), in which the presence of IUF during estrus did not influence the rate of collection of embryos from barren mares when compared with mares which had no IUF during heat. Our results also agree with those of Huhtinen et al. (1996), who showed that a greater number of bacteria and neutrophils in the uterus during foal-heat did not affect the rate of collection of embryos in comparison to the rates of barren mares. Similarly, Rocha (1996) stated that, at ovulation, the vast majority of mares in foal-heat presented a large reduction in the diameter of the uterus (due principally to the effects of steroid hormones), which allowed the mares to maintain gestation.

In the present study, mares presenting IUF during foal-heat (35.1\%) had a greater incidence of IUF accumulation after 
ovulation than mares that did not accumulate IUF during foalheat (15.5\%). Pregnancy rates at D1 4 and D42 post-ovulation were lower in mares with IUF after ovulation (36-48 hours postbreeding) (48.4\% and $41.9 \%$, respectively) than in mares which did not present IUF after ovulation $(74.7 \%$ and $60.6 \%$, respectively). These observations are in agreement with those found in barren mares, in which the post-ovulation accumulation of IUF is an indicator of failure of the physical clearance mechanisms of the uterus, which lead to reduced fertility (LeBlanc, 1989; Pyckok and Newcombe, 1996).

Mares susceptible to persistent post-breeding endometritis frequently accumulate IUF during estrus and the majority present visceroptosis, which results in the uterus being positioned in the abdominal cavity below the level of the pelvis (Troedsson, 1997). Based on uterine diameter, the uterus has an increased volume during foal-heat (Rocha, 1996) and only returns to its pregravidic size at approximately day 23 postpartum (McKinnon et al., 1988). In addition, uterine contractility is reduced between birth and the first ovulation (Griffin and Ginther, 1992). It seems that during foal-heat mares present characteristics similar to those seen in mares susceptible to persistent post-breeding endometritis. The treatment for these animals is based on the elimination of IUF accumulated during heat and help with the physical clearance of the uterus after breeding (Troedsson, 1997).

Treatment of mares presenting IUF during foal-heat with methylergonovine maleate, performed either between the 5th and 10th postpartum day, or 6-12 hours after breeding, did not improve pregnancy rates. In a study that included 311 mares, treatment with methylergovine or cloprostenol during the postpartum period did not affect uterine involution or pregnancy rates of mares bred to foal-heat when compared with untreated mares (Mattos et al., 1995). In addition, uterine flushes with saline solution on days 2 and 4 postpartum did not improve the degree of uterine inflammation or the pregnancy rates (McCue and Hughes, 1990). Presence of IUF was not determined in these two reports. However, the results obtained in the current study permit us to infer that treatments carried out before the first postpartum ovulation to improve uterine involution do not improve pregnancy rates in mares in foal-heat.

The use of oxytocin 6-12 hours post-breeding in mares with a history of accumulation of IUF is an alternative to reduce the incidence of persistent post-breeding endometritis (Troedsson, 1997). The use of methylergonovine maleate, which produces longer and more powerful uterine contractions than oxytocin (Rall and Schleifer, 1987), did not reduce the incidence of postovulation IUF and pregnancy rates in treated mares. It is possible that the size of the uterus and its position prevented the complete drainage of IUF through the cervix after the administration of uterotonic drugs. According to Nikolakopoulos et al. (2000), the administration of oxytocin induces secretion of uterine Prostaglandin- $\mathrm{F}_{2 \alpha}\left(\mathrm{PGF}_{2 \alpha}\right)$, which appears to be an important component of the clearance mechanism of the post-breeding uterus. These authors demonstrated that mares susceptible to persistent post-breeding endometritis secrete less PGF $_{2 \alpha}$ after administration of oxytocin than resistant mares and concluded that this mechanism could be responsible for the differences in uterine contractility in response to experimental infection observed in the two groups of mares. It is possible that the previous endometrial exposure to progesterone is necessary for the secretion of endogenous $\mathrm{PGF}_{2 \alpha}$ induced by the administration of oxytocin (Ginther, 1992). The period between parturition and ovulation, during which the level of progesterone is low, may be long enough to reduce the myometrial sensitivity to uterotonic drugs, which in turn may reduce the intensity of uterine contractions and prevent the complete clearance of the uterus after administration of uterotonic drugs.

According to Asbury and Lyle (1993), uterine lavage is widely used for the physical clearance of the uterus. In that report, it was shown that uterine lavage combined with the administration of oxytocin did not improve pregnancy rates of mares that accumulated IUF after breeding, when compared to mares that did not accumulate IUF. These results are in agreement with those of Mattos et al. (1999), who reported that uterine lavages and administration of oxytocin $24 \mathrm{~h}$ after experimental infection did not affect elimination of bacteria. This inability to eliminate bacteria was probably due to adhesion of the bacteria to the uterine wall. Newcombe (1997) demonstrated that the ability of a mare to maintain pregnancy was the lower the longer a mare retained IUF after ovulation. The mares used in this experiment were examined at intervals of 36-48 hours postbreeding and it was not possible to determine the exact interval between detection of IUF and ovulation. These results demonstrated that the physical clearance of the uterus should be done as soon as possible.

In conclusion the presence of IUF during foal-heat does not affect pregnancy rates, although it does increase the incidence of mares with post-breeding IUF. It was also concluded that treating mares that accumulated IUF during foal-heat with uterotonic drugs did not diminish the incidence of post-ovulation IUF, nor did it improve pregnancy rates. Treating mares that accumulated IUF after foal-heat ovulation with a combination of uterine lavages and oxytocin administration 36 to $48 \mathrm{~h}$ after breeding did not restore pregnancy rates to the levels detected in untreated mares without IUF. It is not possible to determine whether treatment with lavages and oxytocin had any beneficial effect because an untreated control with IUF accumulation was not included in the experiment.

\section{Literature}

Asbury, A.C. and S.K. Lyle (1993): Infectious Causes of Infertility. In: McKinnon, A.O. and J.L. Voss, Equine Reproduction. Philadelphia, Lea and Febiger, 381-391.

Ball, B.A. (1993): Embryonic Death in Mares. In: McKinnon A.O. and J.L. Voss, Equine Reproduction. Philadelphia, Lea and Febiger, 517 531

Brinsko, S.P., D.D. Varner and T.L. Blanchard (1993): Estrogens, Oxytocin, and Ergot Alkaloids. In: McKinnon, A.O. and J.L. Voss, Equine Reproduction. Philadelphia, Lea and Febiger, 334-343.

Ginther, O.J. (1992): Reproductive Biology of the Mare. Cross Plains, Equiservices, 276

Griffin, P.G. and O.J. Ginther (1992): Uterine Morphology and Function during Puerperium in Mares. In: Ginther, O.J. Reproductive Biology of the Mare. Cross Plains, Equiservices, 483.

Huhtinen, M., T. Reilas and T. Katila (1996): Recovery rate and quality of embryos from mares inseminated at the first post-partum oestrus. Acta Vet. Scand. 37, 343-350. 
Hughes, J.P. and R.G. Loy (1975): The Relation of Infection and Infertility in the Mare and Stallion. Equine Vet. J., 7, 155-159

Knutti, B.; J.F. Pycock, G.C. Van Der Wijden and U. Küpfer (2000): The influence of early postbreeding uterine lavage on pregnancy rate in mares with intrauterine fluid accumulations after breeding. Equine Vet. Educ. 12, 276-270

Kurtz Filho, M., N.M Deprá, K.E. Brass, and C.A.M. Silva (1999): Postpartum Fertility in Lactating Thoroughbred Mares. Arq. Fac. Vet. UFRGS, 27, 47-51

LeBlanc, M.M., A.C. Asbury and S.K. Lyle (1989): Uterine Clearance Mechanisms During the Early Postovulatory Period in Mares. Am. J. Vet. Res., 50, 864-867

Mattos, R.C., A.L.A. Rocha, O. Zimmer Jr., R Mattos. V.B. Wald and R.M. Gregory (1995): Use of Methylergonovine Maleate and Cloprostenol during Uterine Involution to Improve Conception Rates of Foal-heat. Biol. Reprod., Mono 1, 533-537

Mattos, R.C., A.P. Neves, R.M. Gregory, M.J.S. Gomes, R. Mattos, M.A. Lagares, A. Keller, V.B. Wald, M.J. Vieira, A.K. Hött (1999): Treatment of endometritis of experimentally infected mares: The effect of ecbolic drugs and plasma enriched with leukocytes on uterine bacterial clearance, Arq. Fac. Vet. UFRGS, 27, 61-72

McCue, P.M. and J.P. Hughes (1990): The effect of postpartum uterine lavage on foal-heat pregnancy rate. Theriogenology 33, 1121-1129

McKinnon, A.O., E.L Squires, L.A. Harrison, E.L. Blach R.K. Shideler (1988): Ultrasonographic studies on the reproductive tract of mares after parturition: Effect of involution and uterine fluid on pregnancy rates in mares with normal and delayed first pospartum ovulatory cycles. JAVMA, 192, 350-353

Merkt, H. and A.R. Günzel (1979): A survey of Early Pregnancy losses in West German Thoroughbred Mares. Equine Vet. J. 11, 256-258

Newcombe, J.R. (1997): The Effect of the Incidence and Depth of Intra-uterine Fluid in Early Diestrus on Pregnancy Rate in Mares. Pferdeheilkunde 13, 545
Nikolakopoulus, E., H.; Kindahl and E.D. Watson (2000): Oxytocin and $\mathrm{PGF}_{2 \alpha}$ Release in Mares Resistant and Susceptible to Persistent Mating-induced Endometritis. J. Reprod. Fertil., 56(suppl.), 363-372

Pycock, J.F., J.R. Newcombe (1996): Assessment of the effect of three treatments to remove intrauterine fluid on pregnancy rate in the mare. Vet. Rec., 138, 320-323

Rall, T.W. and L.S. Schleifer (1987): Ocitocina, Prostaglandina, Alcalóides do Esporão do Centeio e Outras Drogas; Agentes Tocolíticos. In: Goodman, L.S. and A. Gilman, As Bases Farmacológicas da Terapêutica, 7 ed. Rio de Janeiro, Guanabara-Koogan, 605-617

Reilas, T., T. Katila, O. Makela, M. Huhtinen and Koskinen (1997): Intrauterine fluid accumulation in oestrus mares. Acta Vet. Scand. 38, 69-78

Rocha, A.L.A., O. Zimmer Jr., R. Mattos, R.M. Gregory and R.C. Mattos (1996): Características puerperais, taxas de concepção e morte embrionária em éguas Puro Sangue de Corrida cobertas no cio do potro. Arq. Fac. Vet. UFRGS, 24, 65-78

Saltiel, A., A. Gutierrez, N. Buen-Llado and C. Sosa (1987): Cervicoendometrial cytology and physiological aspects of the post-partum mare. J. Reprod. Fert. (suppl), 35, 305-309

Troedsson, M.H.T. (1997): Diseases of the Uterus. In: Robinson, N.E. Current Therapy on Equine Medicine 4..Philadelphia, W.B. Saunders, 517-524

Prod. Dr. Rodrigo C. Mattos

U.F.R.G.S Faculdade de Veterinaria

AV. Bento Goncalves 9090

Porto Alegre, R. S., Brasilien

Tel: 0055-51-3312327

Fax: 0055-51-3195300

Email:RCMattos@vortex.ufrgs.br 